\title{
Cattle use of off-stream water developments across a northeastern Oregon landscape
}

\author{
D.E. Johnson, P.E. Clark, L.L. Larson, K.D. Wilson, M. Louhaichi, T. Freeburg, and J. Williams
}

\begin{abstract}
Water developments have been considered a fundamental tool for dispersing livestock and reducing livestock impact on riparian and aquatic habitats associated with perennial streams. Quantifying the efficacy of water developments has been difficult because of the need to continuously monitor water sources for the timing and intensity of use. The advent of global positioning system (GPS) tracking technology has largely overcome this hurdle and presented new research opportunities. We conducted a five-year study to quantify and evaluate the relative use of existing water developments by cattle on three extensive study areas in northeastern Oregon, United States. Ten randomly selected beef cows from herds grazing each study area were fitted with GPS collars recording animal positions at five-minute intervals throughout the grazing season. Cattle occupancy in $60 \mathrm{~m}(196.9 \mathrm{ft})$ buffers around water developments was determined monthly and annually. Use of water developments was contrasted with that of riparian zones. Cattle use of water developments varied substantially from site-to-site, month-to-month, and year-to-year. In some months, cattle watered exclusively from off-stream developments, and in others, cattle watered nearly exclusively from streams. Substantial differences in the relative use of individual water developments were also seen by season and year. Some developments received no use at all during the five-year study while others were visited frequently. Our results suggest off-stream water development is a useful managerial strategy, but careful placement is required to improve the likelihood that cattle will find and use these water sources and thus decrease their dependence and use of permanent streams and associated riparian areas.
\end{abstract}

Key words: cattle riparian use-livestock water placement-off-stream water developments

Development of wells, reservoirs, springs, and seeps to control livestock distribution has been a primary focus of the rangeland management profession since its inception (Stoddart and Smith 1943; Sampson 1952; Williams 1954). Lack of available drinking water sources restricts the extent of landscape use by livestock (Bailey et al. 1996; Vallentine 2001). Establishment of new water sources at strategic locations can disperse cattle into areas where forages were previously under-utilized (Heady and Child 1994; Ganskopp 2001). Water development can thus simultaneously reduce daily travel distances and improve foraging efficiency of livestock (Valentine 1947). Development of off-stream water sources can also aid in making other tools (e.g., range riding and tree/brush control) for livestock distribution
Controlling livestock use of perennial streams and riparian areas has been a focus of rangeland management research in the Pacific Northwest for many years (Buckhouse et al. 1981; Bryant 1982; Roath and Krueger 1982; Gillen et al. 1985; Green and Kauffman 1995). Research findings concerning the effectiveness of off-stream water developments for livestock management, however, have often been limited, inconclusive, or contradictory (Godwin and Miner 1996; Porath et al. 2002). Limitations associated with previous research techniques and technologies have impeded progress. For example, continuous observation during both day and nighttime of the frequency, duration, and intensity of livestock use near water developments has been difficult to obtain in extensive rangelands. This is especially true in mountainous environments where complex terrain and shrub and tree cover obstruct the field of view. Early attempts at automated monitoring had limited scope and utility (Bentley 1941). The advent of global positioning system (GPS) tracking technology, however, has now largely overcome this monitoring hurdle and presents new opportunities to investigate the efficacy of off-stream water developments.

We initiated a five-year study in 2008 using GPS tracking collars to evaluate the relative use of water developments and permanent streams by beef cattle on three rugged and extensive study areas in northeastern Oregon. Specific objectives of the study were the following:

1. Assess the influence of water-development locations on broad-scale cattle distribution patterns. Clark et al. 2014). Water development may also reduce livestock use and consequent impacts on riparian areas, aquatic habitats, and stream water quality (Gillen et al. 1984; Vallentine 2001).

Concentrated livestock use can damage riparian vegetation, stream banks, and channel morphology (Skovlin 1984; Kauffman et al. 1983a, 1983b; Belsky et al. 1999). Such damage can degrade aquatic habitats for fish and invertebrates (Armour et al. 1991; Strand and Merritt 1999). Grazing livestock can adversely impact stream water quality (Agouridis et al. 2005). However, the occurrence or severity of these impacts are influenced by stocking rate or level of riparian occupancy (Buckhouse and Gifford 1976; Gary 1983).
Douglas E. Johnson is a professor emeritus in the Department of Animal and Rangeland Sciences, Oregon State University, Corvallis, Oregon. Patrick E. Clark is a rangeland scientist for the USDA Agricultural Research Service (ARS) in Boise, Idaho. Larry L. Larson is a retired professor in the Department of Animal and Rangeland Sciences, Oregon State University, Corvallis, Oregon. Kerry D. Wilson is a soil conservationist for the USDA Natural Resources Conservation Service (NRCS) in Pendleton, Oregon. Mounir Louhaichi is a principal rangeland scientist for the International Center for Agricultural Research in Dry Areas (ICARDA), Amman, Jordan. Tyanne Freeburg is with University of Idaho Extension in Moscow, Idaho. John Williams is an associate professor in the Department of Animal and Rangeland Sciences, Oregon State University, Corvallis, Oregon. 
2. Examine the timing and intensity of cattle use near water developments.

3. Investigate the relative impact of offstream water development on riparian use by cattle.

4. Evaluate the characteristics of water developments receiving the greatest and least amount of cattle use.

\section{Materials and Methods}

Site Description. The study areas used in this investigation consist of three grazing allotments on the Wallowa Whitman National Forest in Baker, Union, and Wallowa counties, Oregon. These sites are extensive and cover $439.9 \mathrm{~km}^{2}\left(169.8 \mathrm{mi}^{2}\right)$ (Site $1=217.6$ $\mathrm{km}^{2}$ [84 $\mathrm{mi}^{2}$, Site $2=119.9 \mathrm{~km}^{2}$ [46.3 $\left.\mathrm{mi}^{2}\right]$, and Site $3=102.4 \mathrm{~km}^{2}$ [39.5 $\left.\mathrm{mi}^{2}\right]$ ). They are enclosed in a rectangular area of approximately $47 \mathrm{~km}$ (29.2 mi) east/west by 115 $\mathrm{km}(71.5 \mathrm{mi})$ north/south. The three grazing allotments vary in elevation from $733 \mathrm{~m}$ $(2,405 \mathrm{ft})$ to $2,454 \mathrm{~m}(8,051 \mathrm{ft})$ and are characterized by rugged mountains and uplands that are deeply dissected by canyons. Two of the management areas (Site 1 and Site 2) lay on the southwest flank of the Wallowa Mountains and fall almost completely within the Blue and Seven Devils Mountains Major Land Resource Area (MLRA) just as it transitions from the Central Rocky and Blue Mountain Foothills MLRA (USDA 2006). The third grazing management area (Site 3 ) is located at the northern extent of the Wallowa Mountains and is mostly (twothirds) characterized by the Blue and Seven Devils Mountains MLRA with the southerly third entering into the Palouse and $\mathrm{Nez}$ Perce Prairies MLRA. All are found within the Blue Mountain Ecological Province (Anderson et al. 1998).

Precipitation across these sites averages about $570 \mathrm{~mm}$ (22.4 in) annually with over half occurring between November and March. Precipitation follows the elevation gradient with the most arid areas found in the lower reaches of creeks draining into the Snake River and the greatest precipitation (approximately 1,435 $\mathrm{mm}$ [56.5 in]) found in allotments in the Wallowa Mountains north of Baker, Oregon (Anderson et al. 1998; Prism Climate Group 2014). The elevation range of each study area and the associated 30-year average annual precipitation (Prism Climate Group 2014) are given in table 1.

In the Blue Mountain Province, elevation in combination with aspect, precipitation, and temperature gradients determine potential vegetation, which has been described as a continuum by Hall (1973). The natural vegetation produced under these diverse combinations can be described as approximately a third grasslands with the remainder in forest lands (Anderson et al. 1998).

Cattle Herds. Each spring between 2008 and 2012, 10 mature cows (10\% to $20 \%$ of cohort animals) were randomly selected from commercial livestock herds grazing each study allotment and fitted with a GPS collar to record the date, time, and position at approximately five-minute intervals ( $\mathrm{N}$ $=30$ collared cows $\left.\mathrm{y}^{-1}\right)$. These herds have been grazing their respective study sites for years, and cattle have experience with the landscape, environment, and managerial operations in place. Once initiated, GPS collars were attached to cows, which were transported to study areas where they grazed with herd mates in accordance with ranch and US Forest Service (USFS) grazing management plans. Some USFS allotments (study areas) have adjacent private land inclusions, adjacent private ground, or other federal lease lands that are contiguous with allotments and are also grazed by these herds during the summer grazing season. Thus, collared cattle may go off the allotment for short periods, then return. Turn out dates of livestock vary between study areas from April to June. In the autumn during October or November, at the end of the grazing season, cattle were gathered and returned to their home ranches/winter quarters, where GPS collars were removed and returned to project scientists, and data were downloaded.

During the grazing season, all animals in the herd were treated similarly, but producers and range riders were asked to note the date, time, and location of any collared cattle observed on the range. We assume that the activity, movement, and resource preference of collared animals is representative of other cattle in the herd. The number of collared cattle positions gathered each year and month for each of the study sites are given in table 1.

Data Quality, Handling, and Statistical Analysis. At a five-minute logging interval, we could potentially collect 288 positions for each collared animal each day. Clark GPS collars are programmed to initiate a search for satellites at five-minute intervals; thus, the recorded interval can be extended 15 to 30 seconds beyond the stated logging inter- val. If the collar cannot obtain a satellite fix in a set amount of time, the collar is programmed to shut down and wait for the next collection period. In a test of 1,194 days of data collection during 2008 on Oregon Site 1, collars logged an average of 269 positions $\mathrm{d}^{-1}$. The maximum number of positions recorded during a day in this test was 279 positions, so 10 cows could potentially collect approximately 2,790 positions each day on the site.

Collars can and do fail as they progress through the season and are exposed to animal movement, jolts from cows rubbing on trees and other objects, and changing weather, so we expected fewer active collars towards the end of the grazing season (table 2). In addition, as collars age, their reliability is somewhat decreased in spite of refurbishment and repair. Because cows can move onto or off the allotments in midmonth, the number of positions collected during the month varies. Table 2 provides the mean number of GPS positions collected each month and the number of collars collecting data. The number of cows monitored is important because cattle vary in their ability to travel and disperse. Each collared cow generally represents their subgroup of 5 to 15 cow calf pairs in the overall herd.

Under optimal, open-sky conditions, Clark ATS Collars had a 95\% circular error probability (CEP) of $6.3 \mathrm{~m}(248 \mathrm{ft})$. CEP is the radius of a circle (horizontal) that is centered at the GPS antenna's true position and contains $95 \%$ of the GPS locations. If the position was Wide Area Augmentation System (WAAS)-corrected, the mean 95\% CEP was $2.7 \mathrm{~m}$ (8.8 ft) (Clark et al. 2006). Positional accuracy of GPS receivers are compromised in complex landscapes with deep canyons or locations without a full $180^{\circ}$ sky view. We tested the Clark ATS collar design under extreme conditions in two canyons of northeastern Oregon. This test evaluated 192 sample positional fixes with the Clark ATS while moving at a slow speed, which logged a mean absolute error of 21.5 $\mathrm{m}(70.5 \mathrm{ft})$ with a standard deviation of 23.7 $\mathrm{m}$ (77.8 ft). The maximum error was $146 \mathrm{~m}$ (479 ft). Surprisingly, the largest errors were not in the deepest portions of the canyon, suggesting that large errors were the result of multipath or incomplete trilateration.

To determine cow occupancy on the landscape and in proximity to landscape features, we either counted the number of GPS posi- 
Table 1

Characteristics of the three study allotments used in this investigation.

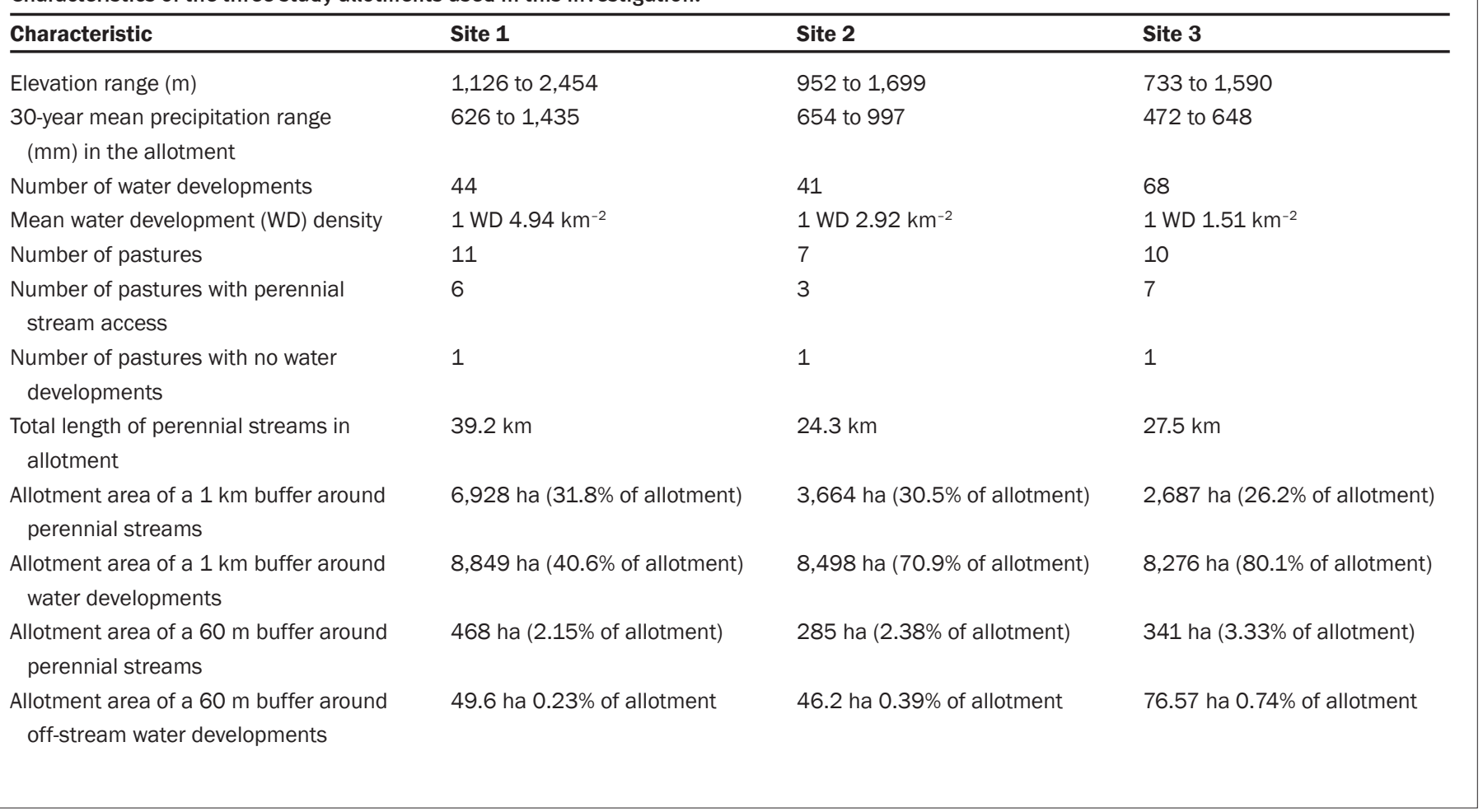

tions within buffers around the feature of interest or we geographically clustered cattle positions on a $30 \mathrm{~m}(98.4 \mathrm{ft})$ grid cell basis with a $90 \mathrm{~m}(295.3 \mathrm{ft})$ search radius to create continuous raster maps for the entire allotment. No Gaussian smoothing was applied. In addition, isolines representing collared cattle occupancy at specific durations and GPS point frequencies per hectare were generated.

Experimental Design. This investigation is largely descriptive in nature and was conducted to provide base information about how livestock interact with water developments on mountainous landscapes. Since the collared animals were selected at random and did not receive special herd management, we assume that the spatial behavior of collared cattle is representative of their subgroup, which usually consists of 5 to 15 herd mates and calves, as well as the entire herd. After collaring, animals resume normal behavior in the herd within 15 minutes. We also propose that the study sites are representative of the region and their combined federal/ private collaborative managerial systems. Comparisons were examined using multifactor analysis of variance (MANOVA) with an a priori significance level of 0.05 (Sokal and Rohlf 2012). If a significant difference was found, means were identified as significantly different with Fisher's Protected Least
Significant Difference (LSD) procedure (Ott and Longnecker 2010). Comparisons were planned for the extent of collared cow occupancy near water developments, both relative intensity of use and the linear extent of stream used by collared cattle.

Also compared were relative occupancy at water developments versus within stream/ riparian buffers by site, and within sites by month and year. In addition, frequency of cattle positions in $60 \mathrm{~m}$ (196.9 ft) buffers around each water development on the three study areas were examined in a geographic information systems context using topographic (elevation, slope, and aspect), road, vegetative/soil, and prior land use activities, as well as satellite and aerial image data to identify factors that contribute to use or disuse by season and site. The $60 \mathrm{~m}$ buffer was selected because it takes longer than five minutes for an animal to travel across the buffer to the water source (at $1 \mathrm{~m} \mathrm{~s}^{-1}[3.3$ $\left.\mathrm{ft} \sec ^{-1}\right]$ ), drink and loaf for four minutes, and exit. No off-stream water developments were within $197 \mathrm{~m}$ (646.3 ft) of perennial streams on these study sites. Correlation of the relationship between collared cow densities at water developments and a $1 \mathrm{~km}$ (0.62 mi) buffer of the land surrounding the development employed the Pearson product moment correlation coefficient (Sokal and Rohlf 2012).

Examination of USFS Allotment Grazing Plans and interviews with range riders and ranchers were also conducted to clarify the recorded pattern of collared cattle movement. General indices of site preference were calculated by dividing the percentage use by collared cattle by the relative percentage of that category on the study site landscape (i.e., if $2 \%$ of all cattle positions are found in 60 m [196.9 ft] buffers around water developments and the surface area of all $60 \mathrm{~m}$ buffers around all water developments is $0.5 \%$ of the study site). This would produce a preference index of 4 , which would indicate a preference for water developments. We apply these indices only in a general sense-index values near zero are avoided, those near one are neutral, and those above one would be preferred (Johnson et al. 2012).

\section{Results and Discussion}

Assessment of the Influence of WaterDevelopment Locations on Cattle Distribution.

Water developments across the allotment permit managers to disperse livestock over a larger area (Heady and Child 1994;Vallentine 2001). To estimate the surface area of the allotment available to cattle without water developments we constructed a $1 \mathrm{~km}(0.62$ 
Table 2

Total number of collared cattle positions logged on each of the study sites each month of the study between 2008 and 2012 and the mean number of collared cattle, across years, that contributed to the data set. The number of observations vary based on the number of functioning collars and the number of days the cattle were on the allotments.

\begin{tabular}{|c|c|c|c|c|c|c|c|}
\hline Site/month & 2008 & 2009 & 2010 & 2011 & 2012 & Total & $\begin{array}{l}\text { Mean number } \\
\text { of cows tracked }\end{array}$ \\
\hline \multicolumn{8}{|l|}{ Site 1} \\
\hline June & 33,325 & 36,642 & - & 33,507 & 24,346 & 127,820 & 9.0 \\
\hline July & 60,323 & 76,000 & 41,614 & 70,030 & 52,499 & 300,466 & 8.6 \\
\hline Aug. & 61,900 & 75,413 & 68,070 & 64,947 & 46,008 & 316,338 & 8.4 \\
\hline Sept. & 46,639 & 63,179 & 56,173 & 57,201 & 20,905 & 244,097 & 7.0 \\
\hline Oct. & 11,609 & 24,709 & 11,458 & 15,795 & 3,140 & 66,711 & 6.4 \\
\hline Total & 213,796 & 275,943 & 177,315 & 241,480 & 146,898 & $1,055,432$ & - \\
\hline \multicolumn{8}{|l|}{ Site 2} \\
\hline June & 44,810 & 69,091 & 51,434 & 28,026 & 25,692 & 219,053 & 7.0 \\
\hline July & 51,112 & 75,650 & 75,661 & 41,038 & 37,865 & 281,326 & 6.8 \\
\hline Aug. & 50,831 & 70,750 & 72,704 & 393,30 & 31,901 & 265,516 & 6.6 \\
\hline Sept. & 46,130 & 60,805 & 67,673 & 31,044 & 28,064 & 233,716 & 6.4 \\
\hline Oct. & 20,268 & 36,723 & 22,630 & 9,586 & 23,085 & 112,292 & 6.2 \\
\hline Total & 213,151 & 313,019 & 290,102 & 149,024 & 146,607 & $1,111,903$ & - \\
\hline \multicolumn{8}{|l|}{ Site 3} \\
\hline Apr. & 37,859 & 7,145 & 24,852 & 27,339 & 19,202 & 116,397 & 8.2 \\
\hline May & 91,360 & 42,321 & 84,638 & 61,201 & 46,619 & 326,139 & 8.6 \\
\hline June & 47,483 & 40,752 & 83,133 & 60,280 & 70,794 & 302,442 & 7.4 \\
\hline July & 38,841 & 41,929 & 77,116 & 56,915 & 49,879 & 264,680 & 7.0 \\
\hline Aug. & 38,634 & 41,199 & 82,410 & 54,901 & 6,912 & 224,056 & 5.4 \\
\hline Sept. & 22,540 & 40,085 & 75,561 & 55,936 & 5,461 & 199,583 & 5.2 \\
\hline Oct. & 0 & 31,470 & 70,061 & 38,463 & 6,196 & 146,190 & 5.5 \\
\hline Total & 276,717 & 244,901 & 497,771 & 355,035 & 205,063 & $1,579,487$ & - \\
\hline Grand total & 703,664 & 833,863 & 965,188 & 745,539 & 498,568 & $3,746,822$ & - \\
\hline
\end{tabular}

mi) buffer on streams.A $1 \mathrm{~km}$ buffer was used because Goebel (1956) suggested that 0.8 to $1.2 \mathrm{~km}(0.5$ to $0.7 \mathrm{mi})$ was the ideal distance between watering points on the Starkey Experimental Range in northeast Oregon. We did the same for water developments, then determined the area of overlap between the two. Table 3 provides an estimate of the area of cattle occupancy with only perennial streams and the potential increased area for cattle occupancy with the current water developments. We know that cattle on level terrain or in areas with well-developed roadways can travel farther than $1 \mathrm{~km}$ to water, and in very rough country they travel less, but this example is illustrative of the value of dispersed water developments on a landscape.

Cattle Distribution on Study Sites. When viewing the cattle GPS data sets in a geographical context, it was immediately obvious that cattle position and movement was the result of managerial objectives, ranch/USFS grazing management plans, prior logging activity, topography, phenology of vegetation (seasonal development and maturation of vegetation), water distribution, and a host of other natural and anthropogenic factors. Many authors have addressed factors controlling livestock distribution (Bryant 1982; Ganskopp and Vavra 1987; Coughenour 1991; Bailey et al. 1996; Wilson 2010).

Perimeter and internal fencing was obviously important because these allotments are subdivided to implement rotational grazing strategies, although fencing is neither complete nor entirely effective between pastures. Also important was the location where livestock enter allotments because that influences the routes that cattle use as they disperse across the landscape and move upward into higher elevation rangelands. Point of entry was used by managers, in conjunction with topography, drift fencing, and water, to alter grazing patterns from year to year. Herding and movement of cattle by range riders also had a major influence on use pattern. This is not surprising since these are controlled landscapes and one primary objective of both producers and USFS personnel is to prevent overuse of vegetation resources, which could result in ecosystem degradation.

When viewed in aggregate across the five years of the study, collared cattle were present on $84.6 \%, 98.6 \%$, and $89.1 \%$ of the allotment surface area for Sites 1,2, and 3, respectively. This implies that water from either streams or water developments is available across the majority of the landscape. Areas not occupied by collared cattle were typically very steep, very rocky, or both.

Timing and Intensity of Cattle Use near Water Developments. Off-stream water has been used to reduce the time that livestock spend in or near streams (Sheffield et al. 1997; Miner et al. 1992). Our GPS collared cattle frequented locations with water developments at a low but relatively consistent rate across the five years of the study (table 4). Cattle on Sites 1 and 2 spent 1\% or less season long near water developments. Cattle on Site 3 spent slightly more than $2.5 \%$ season long near developed water, probably because Site 3 is warmer and somewhat drier than the other sites (table 1). 
Table 3

Surface area of each site that is within $1 \mathrm{~km}$ of a perennial stream, $1 \mathrm{~km}$ of a water development, and the area of overlap between the two. If we assume that the area within $1 \mathrm{~km}$ is a reasonable estimate of area serviced by that water source in this mountainous environment, we can estimate the additional surface area available because of the presence of water developments. This very simple model suggests that water developments have increased the area available for domestic cattle and probably other large ungulates by $94 \%$ to $246 \%$.

\begin{tabular}{lllll}
\hline Site & $\begin{array}{l}\text { Perennial stream } \mathbf{1 ~ k m} \\
\text { buffer area (ha; \% of site) }\end{array}$ & $\begin{array}{l}\text { Water developments } \mathbf{1 ~ k m} \\
\text { buffer area (ha; \% of site) }\end{array}$ & $\begin{array}{l}\text { Perennial stream/ } \\
\text { water development } \\
\text { overlap buffer area (ha) }\end{array}$ & $\begin{array}{l}\text { Estimate increase in potential } \\
\text { area of cattle occupancy } \\
\text { on allotment (ha; \% increase) }\end{array}$ \\
\hline 1 & $6,928(31.8 \%)$ & $8,850(40.7 \%)$ & 2,321 & $6,528(94 \%)$ \\
2 & $3,664(30.6 \%)$ & $8,498(70.9 \%)$ & 3,338 & $5,160(140 \%)$ \\
3 & $2,687(26.2 \%)$ & $8,276(80.8 \%)$ & 1,656 & $6,619(246 \%)$
\end{tabular}

When viewed on a monthly basis, there were no recorded positions within $60 \mathrm{~m}$ $(196.9 \mathrm{ft})$ of a water development on Site 1 during June of 2008 and 2011 and on Site 3 in April of 2009 and 2011 (table 4). These were periods when pasture rotation and herding placed cattle in close proximity to perennial streams. Conversely, the same factors placed animals in locations with little or no perennial stream access during other periods of the grazing season. The highest levels of water development use on Site 1 was in August and October of 2012, while on Sites 2 and 3 it was respectively August and September of 2011 and June and July of 2008 (table 4). Based on proportionate surface area of the $60 \mathrm{~m}$ buffers, cattle occupancy on all three sites demonstrated a strong preference for developed water (Site 1, 2.9; Site 2, 2.07; Site 3, 3.18).

Relative Impact of Off-Stream Water Developments on Riparian Use by Cattle. We observed that in some months, collared cattle positions were predominately found on perennial streams, while in other months, positions were almost exclusively near the off-stream water developments and that the fluctuation between years and months could be great. For example, perennial stream use on Site 1 in June and July across all five years of the study varied from $3.7 \%$ to $92.1 \%$ and $6.9 \%$ and $95.1 \%$, respectively (table 5 ). This variation was traced to the rotational grazing plan, which encouraged cattle to utilize the terrain and off-road vehicle trails along streams as travel routes. In other examples, some pastures lacked perennial streams and animals were restricted to water developments. Similarly, the use of entry points into an allotment that are not near perennial streams encourage livestock watering from ponds, tanks, and troughs until they drift into foraging areas that are close to perennial streams.

Conversely, on Site 3 during June, July, August, and September, 95\% of the cattle positions proximate to water were near
Table 4

Percentage of all recorded collared cattle GPS positions that were within $60 \mathrm{~m}$ of a water development for each study site by year. Water developments include developed springs, ponds, reservoirs, and pit tanks (we should note that many other locations on the landscape could contain puddles or seeps that livestock would use for water in the spring or after summer rains).

\begin{tabular}{|c|c|c|c|c|c|c|}
\hline \multirow[b]{2}{*}{ Site/month } & \multicolumn{6}{|c|}{ Recorded collared cattle positions within $60 \mathrm{~m}$ of a water development (\%) } \\
\hline & 2008 & 2009 & 2010 & 2011 & 2012 & Mean \\
\hline \multicolumn{7}{|l|}{ Site 1} \\
\hline June & 0.00 & 0.20 & NA & 0.00 & 0.50 & 0.17 \\
\hline July & 0.64 & 0.14 & 0.94 & 0.31 & 0.80 & 0.56 \\
\hline Aug. & 0.43 & 0.19 & 1.25 & 0.07 & 2.19 & 0.82 \\
\hline Sept. & 1.07 & 0.18 & 0.75 & 0.67 & 0.62 & 0.65 \\
\hline Oct. & 0.27 & 0.71 & 0.63 & 0.02 & 9.94 & 2.31 \\
\hline Season long & 0.55 & 0.22 & 0.98 & 0.27 & 1.36 & 0.67 \\
\hline \multicolumn{7}{|c|}{ Site 1 surface area of $60 \mathrm{~m}$ buffer on water developments $=0.23 \%$ of allotment } \\
\hline \multicolumn{7}{|c|}{ Site 2} \\
\hline June & 0.27 & 0.57 & 0.27 & 0.38 & 1.08 & 0.51 \\
\hline July & 0.72 & 1.63 & 1.00 & 1.44 & 0.41 & 1.04 \\
\hline Aug. & 0.84 & 0.50 & 1.17 & 1.80 & 0.11 & 0.88 \\
\hline Sept. & 0.81 & 0.36 & 0.61 & 1.67 & 0.16 & 0.72 \\
\hline Oct. & 0.76 & 0.30 & 0.64 & 0.86 & 0.95 & 0.70 \\
\hline Season long & 0.68 & 0.74 & 0.79 & 1.35 & 0.50 & 0.81 \\
\hline \multicolumn{7}{|c|}{ Site 2 surface area of $60 \mathrm{~m}$ buffer on water developments $=0.39 \%$ of allotment } \\
\hline \multicolumn{7}{|c|}{ Site 3} \\
\hline Apr. & 0.20 & 11.64 & 0.15 & 0.07 & 0.01 & 2.41 \\
\hline May & 1.72 & 2.50 & 0.08 & 1.55 & 1.31 & 1.43 \\
\hline June & 3.95 & 4.94 & 1.75 & 1.74 & 2.76 & 3.03 \\
\hline July & 7.20 & 4.82 & 2.23 & 4.90 & 4.91 & 4.81 \\
\hline Aug. & 1.82 & 1.42 & 1.99 & 2.70 & 3.01 & 2.19 \\
\hline Sept. & 3.39 & 5.03 & 1.39 & 4.68 & 3.19 & 3.53 \\
\hline Oct. & NA & 0.70 & 1.89 & 1.40 & 2.95 & 1.73 \\
\hline Season long & 2.81 & 3.57 & 1.47 & 2.66 & 2.72 & 2.64 \\
\hline \multicolumn{7}{|c|}{ Site 3 surface area of $60 \mathrm{~m}$ buffer on water developments $=0.83 \%$ of allotment } \\
\hline Grand mean & 1.48 & 1.40 & 1.17 & 1.62 & 1.67 & 1.44 \\
\hline
\end{tabular}


Table 5

Relative percentage of all livestock positions that were either within $60 \mathrm{~m}$ of a water development (WD) or within $60 \mathrm{~m}$ of a perennial stream (PS). Data has been partitioned by each month of the grazing season and season long on the three study sites in northeastern Oregon.

\begin{tabular}{|c|c|c|c|c|c|c|c|c|c|c|c|c|}
\hline \multirow[b]{3}{*}{ Site/month } & \multicolumn{12}{|l|}{ Year } \\
\hline & \multicolumn{2}{|l|}{2008} & \multicolumn{2}{|l|}{2009} & \multicolumn{2}{|l|}{2010} & \multicolumn{2}{|l|}{2011} & \multicolumn{2}{|l|}{2012} & \multicolumn{2}{|c|}{ All years } \\
\hline & WD $\%$ & PS $\%$ & WD $\%$ & PS $\%$ & WD\% & PS $\%$ & WD $\%$ & PS $\%$ & WD $\%$ & PS $\%$ & WD $\%$ & PS $\%$ \\
\hline \multicolumn{13}{|l|}{ Site 1} \\
\hline June & 96.3 & 3.7 & 7.9 & 92.1 & - & 49.5 & 50.5 & 35.1 & 64.9 & 47.2 & 52.8 & \\
\hline July & 40.9 & 59.1 & 11.1 & 88.9 & 93.1 & 6.9 & 4.9 & 95.1 & 36.9 & 63.1 & 37.4 & 62.6 \\
\hline Aug. & 16.2 & 83.8 & 14.8 & 85.2 & 59.8 & 40.2 & 1.9 & 98.1 & 46.8 & 53.2 & 27.9 & 72.1 \\
\hline Sept. & 55.6 & 44.4 & 19.4 & 80.6 & 48.2 & 52.8 & 19.0 & 81.1 & 8.3 & 91.7 & 30.1 & 69.9 \\
\hline Oct. & 11.1 & 88.9 & 44.0 & 56.0 & 25.9 & 74.1 & 1.0 & 99.0 & 100.0 & 0.0 & 36.4 & 63.6 \\
\hline Season long & 44.0 & 56.0 & 19.4 & 80.6 & 56.8 & 43.3 & 15.3 & 84.7 & 45.4 & 54.6 & 35.8 & 64.2 \\
\hline \multicolumn{13}{|l|}{ Site 2} \\
\hline June & 11.3 & 88.7 & 100.0 & 0.0 & 100.0 & 0.0 & 100.0 & 0.0 & 100.0 & 0.0 & 82.3 & 17.7 \\
\hline July & 24.8 & 75.2 & 100.0 & 0.0 & 88.0 & 12.0 & 100.0 & 0.0 & 100.0 & 0.0 & 82.5 & 17.5 \\
\hline Aug. & 9.4 & 90.6 & 10.9 & 89.1 & 14.9 & 85.1 & 52.7 & 47.3 & 0.6 & 99.4 & 17.7 & 82.3 \\
\hline Sept. & 7.1 & 92.9 & 5.5 & 94.5 & 13.3 & 86.7 & 18.2 & 81.8 & 1.7 & 98.3 & 9.2 & 90.8 \\
\hline Oct. & 41.8 & 58.2 & 9.9 & 90.1 & 30.6 & 69.4 & 9.5 & 90.5 & 19.5 & 80.5 & 22.3 & 77.7 \\
\hline Season long & 18.9 & 81.1 & 45.3 & 54.7 & 49.4 & 50.6 & 56.1 & 43.9 & 44.4 & 55.6 & 42.8 & 57.2 \\
\hline \multicolumn{13}{|l|}{ Site 3} \\
\hline Apr. & 3.9 & 96.1 & 89.8 & 10.2 & 1.4 & 98.6 & 0.4 & 99.6 & 0.1 & 99.9 & 19.1 & 80.9 \\
\hline May & 49.4 & 50.6 & 73.5 & 26.5 & 2.8 & 97.2 & 20.9 & 79.1 & 10.7 & 89.3 & 31.5 & 68.5 \\
\hline June & 100.0 & 0.0 & 100.0 & 0.0 & 74.3 & 25.7 & 98.2 & 1.8 & 100.0 & 0.0 & 94.5 & 5.5 \\
\hline July & 100.0 & 0.0 & 100.0 & 0.0 & 56.7 & 43.3 & 100.0 & 0.0 & 100.0 & 0.0 & 91.3 & 8.7 \\
\hline Aug. & 100.0 & 0.0 & 100.0 & 0.0 & 99.4 & 0.6 & 99.7 & 0.3 & 100.0 & 0.0 & 99.8 & 0.2 \\
\hline Sept. & 100.0 & 0.0 & 100.0 & 0.0 & 100.0 & 0.0 & 99.9 & 0.1 & 100.0 & 0.0 & 100.0 & 0.0 \\
\hline Oct. & - & - & 100.0 & 0.0 & 95.3 & 4.7 & 99.6 & 0.4 & 75.6 & 24.4 & 92.6 & 7.4 \\
\hline Season long & 75.6 & 24.5 & 94.6 & 5.2 & 61.4 & 38.6 & 74.1 & 25.9 & 69.5 & 30.5 & 75.5 & 24.5 \\
\hline
\end{tabular}

off-stream water developments. This pattern reflects the movement of livestock in April and May from lower valley positions containing perennial streams into the uplands where the only water available was from water developments. The timing of this move to the uplands controls when cattle switch from watering in streams to watering from off-stream ponds, springs, and troughs.

Although there is substantial year-to-year variability, table 5 indicates that across the five years of this study, Site 1 had $35.8 \%$ of all collared cow GPS locations proximate to water at water developments. Site 2 had $42.8 \%$ and Site 3 had $75.5 \%$ of all collared cow GPS locations proximate to water at water developments. Thus, water developments play a major role in the use and dispersal of cattle across this landscape. The next obvious question is whether perennial stream use on these sites have led to overuse or noncompliance with USFS regulations regarding stream health. None of our sites were out of compliance during this study. The pattern of use, which includes reliance on perennial streams during all or portions of the year, have been deemed acceptable by today's USFS riparian health standards.

Water Developments with the Greatest Cattle Use. Water developments in this region consist only of natural surface sources; there are no sites where water is hauled to tanks and no sites where wells tap ground water. Thus, development of water for livestock can only occur where springs, seeps, or surface terrain concentrate water in sufficient quantity for domestic stock or wildlife. Still, the developments are relatively broadly distributed across the landscapes on the three study sites. Water developments showed tremendous variability in their relative use by collared cattle within sites (table 6).

Out of the 44 water developments located on Site 1, 35\% of all cow locations plotted near a water development were found at a single spring with an associated tank. If the second most frequent location is added, over half of all cattle positions proximate to water developments are accounted for (table 6). This is not to say that other water develop- ments on this site are unimportant-many are used for short periods by cattle when grazing specific areas or as water sources along travel routes from one area of the allotment to another. In addition, water developments are commonly used by many types of wildlife, including insects, birds, rodents, and game mammals. Of the 10 most frequently used water developments, 4 were ponds and 6 were developed springs with metal troughs or tanks (table 6). All of these high value locations were in "Satisfactory" or "Good" condition.

Site 2 shows a similar pattern of cattle occupancy within $60 \mathrm{~m}$ (196.9 ft) of water developments (table 5). Again, nearly 50\% of all collared cow positions were found near only 2 of the 41 water developments on the site. On Site 2, we found that 4 of the 10 most frequently used water developments were ponds, with the remaining 6 developed springs with metal troughs or tanks. One of these was in "Critical" condition, one in "Poor" condition, and the others were either "Satisfactory" or "Good." 


\section{Table 6}

The number of collared cow positions near $(<60 \mathrm{~m})$ all water developments over the period from 2008 to 2012 for Site 1. The water improvement type and condition are provided for those developments that comprised $1 \%$ or more of the cow-water development interactions on the site. Nineteen water developments had less than 25 collared cow positions in the $60 \mathrm{~m}$ buffer around the development of which 6 had no cow positions.

\begin{tabular}{|c|c|c|c|c|c|c|}
\hline Site & Source & Type & $\begin{array}{l}\text { Five-year usage as } \\
\% \text { of points collected } \\
\text { near developments }\end{array}$ & Rank & $\begin{array}{l}\text { Cumulative (five-year) } \\
\text { collared cow count }\end{array}$ & $\begin{array}{l}\text { Cumulative (five-year) collared } \\
\text { cow hours of occupancy }\end{array}$ \\
\hline \multirow[t]{5}{*}{1} & Spring & Tank & 35.5 & 1 & 2,279 & 190 \\
\hline & Spring & Tank & 16.1 & 2 & 1,035 & 86 \\
\hline & Ponds (4) & Earth & 24.8 & Within top 10 & 1,598 & 133 \\
\hline & Springs (6) & Tank & 62.1 & Within top 10 & 3,994 & 333 \\
\hline & Remaining 34 & Various & 13.0 & - & 839 & 70 \\
\hline \multirow[t]{5}{*}{2} & Spring & Tank & 29.2 & 1 & 2,569 & 214 \\
\hline & Spring & Tank & 17.6 & 2 & 1,546 & 129 \\
\hline & Ponds (4) & Earth & 13.7 & Within top 10 & 1,203 & 100 \\
\hline & Spring (6) & Tank & 68.2 & Within top 10 & 5,831 & 485 \\
\hline & Remaining 32 & Various & 18.0 & - & 1,767 & 147 \\
\hline \multirow[t]{5}{*}{3} & Pond & Earth & 11.2 & 1 & 4,491 & 374 \\
\hline & Pond & Earth & 9.6 & 2 & 3,834 & 319 \\
\hline & Pond (7) & Earth & 44.5 & Within top 10 & 19,188 & 1,488 \\
\hline & Spring (3) & Tank & 13.1 & Within top 10 & 3,930 & 438 \\
\hline & Remaining 58 & Various & 42.4 & - & 16,071 & 1,339 \\
\hline
\end{tabular}

The most dispersed use of water developments occurred on Site 3. The two most frequent water developments accounted for less than $21 \%$ of all collared cow positions (table 5). There were 28 locations that had more than $1 \%$ use, and the 10 most used water developments accounted for nearly $58 \%$ of all logged use (table 5). Of the 10 most frequently used water developments on Site 3, 8 were ponds (including one fenced pond with a tank) and 2 were developed springs with metal troughs or tanks (table 5). One pond was in "Poor" condition, in need of repair, and the rest were in "Satisfactory" or "Good" condition.

Of the three sites studied, the most mesic and coolest was Site 1 and the driest and warmest was Site 3 (table 1). Site 1 had a total of 6,427 collared cow locations near water developments over the five years of the study, Site 2 had 8,801 locations, and Site 3, adjusted for the same five months monitored on Sites 1 and 2, had 33,633 locations. The permanent streams on Site 3 are located at the lowest elevation levels with water developments much higher on the site. Because of this elevation difference, collared cattle relied more heavily on water developments in mid and late summer. Site 3 has more open grassland and less forested areas, which would provide shade and protection from wind, which also could potentially increase water demand.

What Are the Characteristics of Water Developments that Receive the Greatest Use?
We hypothesized that proximity of the water source to the foraging/resting positions on the landscape influenced selection. Those sites closest to areas with high collared cow density would be the most heavily used. Both Sites 2 and 3 are at lower elevation than Site 1 and have lower 30-year average amounts of annual precipitation compared to Site 1 (table 1). On Site 1, water developments that received the highest use were those that were also close to areas where cattle tend to congregate. For example, on Site 1 the number of cow positions within $1 \mathrm{~km}$ (0.62 mi) of a water development was positively correlated with the number of collared cow positions within $60 \mathrm{~m}(196.9 \mathrm{ft})$ of the water development $(r=0.740)$. Thus, high use areas of the landscape tended to have highly used water developments, but the relationship was not perfect. Some water developments located near roads used to move livestock were frequently used, yet had low animal counts within $1 \mathrm{~km}$. This suggests that the water is used during transit between areas. When we regressed the number of counts within $60 \mathrm{~m}$ of a water development on the count within $1 \mathrm{~km}$, the result was $\hat{Y}=0.0152 x-$ $114.42\left(R^{2}=0.333\right)$ where $x$ represents the number of cow locations within $1 \mathrm{~km}$. This weak relationship indicates that other factors are influencing the selection of watering locations. These other factors are most likely related to ease of travel from grazing/resting areas to watering locations. Ganskopp et al. (2000) have suggested that cattle follow least-effort pathways, and this is likely the case on this site.

Site 2 had many areas that cattle frequented that were more than $1 \mathrm{~km}(0.62$ mi) from water. In contrast to Site 1 , the number of cow positions on Site 2 within $1 \mathrm{~km}$ of a water development was weakly positively correlated with the number of collared cow positions within $60 \mathrm{~m}(196.9 \mathrm{ft})$ of the water development $(r=0.287)$. When we regressed the number of counts within $60 \mathrm{~m}$ of a water development on the count within $1 \mathrm{~km}$, the result was $\hat{Y}=0.0055 x+$ $44.542\left(R^{2}=0.0826\right)$ where $x$ represents the number of cow locations within $1 \mathrm{~km}$. While some heavily used water developments were close to areas commonly used by cattle, other proximate water developments were infrequently used. The little-used developments were generally up an elevation gradient, sometimes as little as 70 vertical meters $(229.7 \mathrm{ft})$ higher. Other developments were on the other side of a ridge, which tended to topographically separate the frequently used areas from watering locations. Obviously, slope gradient, ease of travel, and route play a critical role in determining which water developments are selected. On this site, we also saw clusters of water developments that had lower use numbers individually because they were close to the same occupancy foci on the landscape. 
The number of cow positions on Site 3 within $1 \mathrm{~km}(0.62 \mathrm{mi})$ of a water development was weakly positively correlated with the number of collared cow positions within $60 \mathrm{~m}(196.9 \mathrm{ft})$ of the water development $(r$ $=0.212$ ). When we regressed the number of counts within $60 \mathrm{~m}$ of a water development on the count within $1 \mathrm{~km}$, the result was $\hat{Y}$ $=0.0063 x+203.74\left(R^{2}=0.0448\right)$ where $x$ represents the number of cow locations within $1 \mathrm{~km}$ of the water development. As with Site 2, this is a relatively weak overall relationship, caused by having a number of water development locations within areas with high animal density.

Of the 10 most frequently used water development sites $(<60 \mathrm{~m}[<196.9 \mathrm{ft}])$ in Site 3 , all were on rolling uplands near the center of foci of collared cattle occupancy. These developments were typically near the top of deeply dissected canyons. Seven of the 10 water developments were ponds, 4 of which retain water year round and 3 that become dry during late summer. Ponds generally have higher capacity and can accommodate more cattle simultaneously than troughs, and this may be a factor in their selection. We should note that the rolling terrain of these water developments provides relatively easy access over distances greater than $1 \mathrm{~km}$ (0.62 mi).

Many of the water developments on all the study sites were within $100 \mathrm{~m}$ (328.1 $\mathrm{ft}$ ) of roadways or jeep trails that facilitated cattle movement because the grade has been moderated. It is obvious from our analysis that there are many factors controlling animal use of water developments. Some of them are broad scale such as terrain, forage availability moderated by soils, and plant communities, while others are fine scale factors such as water quality, downed trees on trails, local trail gradient, etc.

Allotment grazing plans and herding by ranchers and range riders profoundly influenced the pattern of use of water developments across years, primarily by channeling the herds across the landscape so that areas are grazed in different sequence or to provide rest to portions of the allotment.

\section{Summary and Conclusions}

Water developments were created on our mountainous landscapes beginning with the arrival and settling of European Americans and continues to the present. Many watering locations exist on USFS Allotments (Site 1 = 1 water development $4.94 \mathrm{~km}^{-2}\left[1.9 \mathrm{mi}^{-2}\right]$,
Site $2=1$ water development $2.92 \mathrm{~km}^{-2}$ [1.13 $\mathrm{mi}^{-2}$, and Site $3=1$ water development 1.51 $\left.\mathrm{km}^{-2}\left[0.58 \mathrm{mi}^{-2}\right]\right)$ that are maintained by the USFS personnel and cooperating ranchers. Information collected in this study suggests that cattle use the off-stream water developments extensively and they increase both the surface area of the allotment available for grazing and managerial flexibility. We can also reasonably infer that wildlife also rely heavily on water developments. Each study site was unique and the location of water developments reflected the limitations of water availability, which is a function of the topography, lithology, and structural geology of the sites.

When individually compared, some watering locations receive very high use while others are rarely used. These high-use watering sites permit cattle to range further from streams, springs, and seeps into drier areas of the allotments. This is especially true during the drier seasons: mid to late summer/autumn. During some months on some sites, water is nearly exclusively obtained from water developments, in others almost exclusively from perennial streams. It is clear that the managers in the past who scouted, planned, and developed springs, ponds, and catchment basins understood the value of dispersed watering points on the landscape. It is also obvious that some of these water developments were not as effective as others. Those that were used most frequently were accessible from high-use cattle foci on the landscape by either moderate terrain or by established roads or jeep trails.

Knowledge of where and when livestock graze extensive landscapes coupled with the visitation frequency of existing water developments can indicate where new developments should be placed. Specific problems of livestock dispersal can be addressed rationally if grazing patterns and water usage are known. Occupancy patterns can also indicate which water developments must be maintained if current grazing systems are to be effective and which areas are heavily dependent on single sources. In some cases, a redundant water source close by may provide backup in the event of the failure of the principle source. We suggest that GPS data collected on cattle provides a clearer picture of actual use of the landscape and facilitates formulation of rational managerial options that promote sustainable range/livestock systems.

\section{Acknowledgements}

The authors gratefully acknowledge the following organizations and individuals for funding, cooperation, and technical and logistic support: (1) USDA National Institute of Food and Agriculture ("Developing an Adaptive Management System and its Components to Address Effects of Gray Wolf Reintroduction on Ecosystem Services" Agency Number: 2010-85101-20512 and "Development Of Planning and Monitoring Elements of an Adaptive Management 426 System for Wolf-Livestock Relations" NIFA Project No. 5362-13610-009-06R), (2) Oregon Beef Council, (3) Oregon State University/Oregon Agricultural Experiment Station, (4) USDA/Agricultural Research Service, (5) University of Idaho, (6) International Center for Agricultural Research in the Dry Areas (ICARDA), and (7) farm and ranch families on the research sites. Animals were handled in accordance with Oregon State University animal handling protocols under permit ACUP \# 4555.

\section{References}

Agouridis, C.T., S.R. Workman, R.C. Warner, and G.D. Jennings. 2005. Livestock grazing management impacts on stream water quality: A review. Journal of the American Water Resources Association 41:591-606.

Anderson, E.W., M.M. Borman, and W.C. Krueger. 1998. The ecological provinces of Oregon, a treatise on the basic ecological geography of the state. Oregon Agricultural Experiment Station SR 990, OR: Oregon State University.

Armour, C.L., D.A. Duff, and W. Elmore. 1991. The effects of livestock grazing on riparian and stream ecosystems. Fisheries 16:7-11.

Bailey, D.W., J.E. Gross, E.A. Laca, L.R. Rittenhouse, M.B. Coughenour, D.M. Swift, and P.L. Sims. 1996. Mechanisms that result in large herbivore grazing distribution patterns. Journal of Range Management 49:386-400.

Belsky, A.J., A. Matzke, and S. Uselman. 1999. Survey of livestock influences on stream and riparian ecosystems in the western United States. Journal of Soil and Water Conservation 54(1):419-431.

Bentley, J.R. 1941. Automatic recording of salting and watering habits of cattle. Journal of Forestry 39:832-836.

Bryant, L.D. 1982. Response of livestock to riparian zone exclusion. Journal of Range Management 35(6):780-785.

Buckhouse, J.C., and G.F. Gifford. 1976. Water quality implications of cattle grazing on a semiarid watershed in southeastern Utah. Journal of Range Management 29:109-113.

Buckhouse, J.C., J.M. Skovlin, and R.W. Knight. 1981. Streambank erosion and ungulate grazing relationships. Journal of Range Management 34:339-340.

Clark, P.E., D.E. Johnson, M.A. Kniep, P. Jermann, B. Huttash, A. Wood, M. Johnson, C. McGillivan, and K. Titus. 2006. An advanced, low-cost, GPS-based animal 
tracking system. Rangeland Ecology and Management 59(3):334-340.

Clark, P.E., J. Lee, K. Ko, R.M. Nielson, D.E. Johnson, D.C. Ganskopp, J. Chigbrow, F.B. Pierson, and S.P. Hardegree. 2014. Prescribed fire effects on resource selection by cattle in mesic sagebrush steppe. Part 1: Spring grazing. Journal of Arid Environments 100-101:78-88.

Coughenour, M.B. 1991. Spatial components of plantherbivore interactions in pastoral, ranching and native ungulate ecosystems. Journal of Range Management 44(6):530-542.

Ganskopp, D. 2001. Manipulating cattle distribution with salt and water in large arid-land pastures: A GPS/ GIS assessment. Applied Animal Behaviour Science $73: 251-262$.

Ganskopp, D., and M.Vavra. 1987. Slope use by cattle, feral horses, deer, and bighorn sheep. Northwest Science 61:74-81.

Ganskopp, D., R. Cruz, and D.E. Johnson. 2000. Least-effort pathways? A GIS analysis of livestock trails in rugged terrain. Applied Animal Behaviour Science 68:179-190.

Gary, H.L. 1983. Cattle grazing impact on surface water quality in a Colorado Front Range stream. Journal of Soil and Water Conservation 38(2):124-128.

Gillen, R.L., W.C. Krueger, and R.F. Miller. 1984. Cattle distribution on mountain rangeland in Northeastern Oregon. Journal of Range Management 37:549-553.

Gillen, R.L., W.C. Krueger, and R.F. Miller. 1985. Cattle use of riparian meadows in the Blue Mountains of northeastern Oregon. Journal of Range Management 38:205-209.

Godwin, D.C., and J.R. Miner. 1996. The potential of off-stream livestock watering to reduce water quality impacts. Bioresource Technology 58:285-290.

Goebel, C.J. 1956. Water development on the Starkey Experimental Forest and Range. Journal of Range Management 9:232-234.

Green, D.M., and J.B. Kauffman. 1995. Succession and livestock grazing in a northeastern Oregon riparian ecosystem. Journal of Range Management 48:307-313.

Hall, F.C. 1973. Plant communities of the Blue Mountains in eastern Oregon and southeastern Washington. R-6 Area Guide 3-1. USDA Forest Service, OR: Pacific Northwest Region.

Heady, H.F., and R.D. Child. 1994. Rangeland Ecology and Management. San Francisco, CA: Westview Press.

Johnson, D.E., P.E. Clark, L.L. Larson, M. Louhaichi, and J. Williams. 2012. Beef Council Report: Wolf Cattle Interaction Study. Research report to Oregon Beef Council, Department of Rangeland Ecology and Management, OR: Oregon State University.

Kauffman, J.B., W.C. Krueger, and M.Vavra. 1983a. Impacts of cattle on streambanks in northeastern Oregon. Journal of Range Management 36:683-685.
Kauffman, J.B., W.C. Krueger, and M.Vavra. 1983b. Effects of late season cattle grazing on riparian plant communities. Journal of Range Management 36:685-691.

Miner, J.R., J.C. Buckhouse, and J.A. Moore. 1992. Will a water trough reduce the amount of time hay-fed livestock spend in the stream (and therefore improve water quality)? Rangelands 14:35-38.

Ott, R.L., and M.T. Longnecker. 2010. An introduction to statistical methods and data analysis, 6th edition. Belmont, CA: Brooks/Cole Cengage Learning.

Porath, M.L., P.A. Momont, T. Delcurto, N.R. Rimbey, J.A. Tanaka, and M. McInnis. 2002. Offstream water and trace mineral salt as management strategies for improved cattle distribution. Journal of Animal Science 80:346-356.

PRISM Climate Group. 2014. 30-yr normal precipitation: Annual. http://www.prism.oregonstate.edu/normals/.

Sampson, A.W. 1952. Range management, principles, and practices. NY: John Wiley and Sons.

Roath, L.R., and W.C. Krueger. 1982. Cattle grazing influence on a mountain riparian zone. Journal of Range Management 35:100-104.

Sheffield, R.E., S. Mostaghimi, D.H. Vaughan, E.R. Jr. Collins, and V.G. Allen. 1997. Off-stream water sources for grazing cattle as a stream bank stabilization and water quality BMP. Transactions of the American Society of Agricultural Engineers (ASAE) 40(3):595-604.

Skovlin, J.M. 1984. Impacts of grazing on wetlands and riparian habitat: A review of our knowledge. In Developing Strategies for Rangeland Management, 1001-1103. National Research Council/National Academy of Science. Boulder, CO: Westview Press.

Sokal, R.R., and FJ. Rohlf. 2012. Biometry: The principles and practice of statistics in biological research, 4th edition. NY:W.H. Freeman and Co.

Strand, M., and R.W. Merritt. 1999. Impacts of livestock grazing activities on stream insect communities and the riverine environment. American Entomologist 45:13-29.

Stoddart, L.A., and A.D. Smith. 1943. Range management. NY: McGraw-Hill.

USDA. 2006. USDA: Agriculture Handbook 296. Major Land Resource Regions Custom Report. Washington, DC: US Government Publishing Office.

Valentine, K.A. 1947. Distance from water as a factor in grazing capacity of rangeland. Journal of Forestry 45:749-754.

Vallentine, J.F. 2001. Grazing Management. 2nd edition. San Diego, CA: Academic Press.

Williams, R.E. 1954. Modern methods of getting uniform use of ranges. Journal of Range Management 7:77-81.

Wilson, K.D. 2010. Landscape occupancy by free ranging cattle in Northeast Oregon. Master's thesis, Oregon State University. 